\title{
PENGEMBANGAN MEDIA PEMBELAJARAN INTERAKIF BIOLOGI UNTUK MENINGKATKAN HASIL BELAJAR SISWA SMP
}

\author{
Gede Ari Yudasmara ${ }^{1}$ \\ Desi Purnami ${ }^{2}$ \\ ${ }^{1}$ Universitas Pendidikan Ganesha, Jln. Udayana No. 11 Singaraja \\ ${ }^{2}$ SMP Negeri 3 Kintamani, Satera Bangli \\ e-mail: ariyudasmara@gmail.com
}

\begin{abstract}
Developing Interactive Instructional Media in Biology to Improve Junior High School Students' Achievement. This study aimed to produce interactive instructional media interactive which is practical, and effective. This research was a research and development, which washeld in SMP Negeri 3 Bangli Kintamani to the class VIIIA in the Odd semester of the school year 2014/2015. The subjects were Biology teacher and eighth grade students of class VIIIA. The data were analyzed using descriptive analysis related to aspects of practicality and effectiveness through a questionnaire and Biology achievement test. The result shows that 1) the media that was developed has fulfilled the criteria of practicality based on the average score of the response of teachers to 3.73 (categorized positive) and the students' responses 3.5 (categorized very positive) and 2) interactive instructional media of Biology has accomplished the criteria of effectiveness because it has reached the learning outcomes of the test scores of students who achieved an average of 79.04 above $K K M$ (the minimum criteria of mastery) from previously determined 72 , and the percentage of students achieving the minimum criteria of mastery is $95.83 \%$.
\end{abstract}

Keywords: instructional media, learning achievement, quality of media

\begin{abstract}
ABSTRAK:Pengembangan Media Pembelajaran Interakif Biologi untuk Meningkatkan Hasil Belajar Belajar Siswa SMP. Penelitian ini bertujuan untuk menghasilkan media pembelajaran interaktif biologi yang praktis, dan efektif. Penelitian ini merupakan penelitian pengembangan, yang dilaksanakan di SMP Negeri 3 Kintamani Bangli, pada kelas VIIIA semester Ganjil tahun pelajaran 2014/2015. Subjek penelitian ini adalah guru Biologi dan siswa kelas VIIIA SMP Negeri 3 Kintamani. Teknik analisis data menggunakan analisis deskriptifyang berkaitan dengan aspek kepraktisan dan efektivitas melalui angket dan tes hasil belajar biologi siswa. Hasil analisis data menunjukkan bahwa 1) media pembelajaran yang berhasil dikembangkan telah memenuhi syarat kepraktisan berdasarkan rata-rata nilai respon guru 3,73 (terkategori positif) dan respon siswa 3,5 (terkategori sangat positif) dan 2) Media pembelajaran interaktif biologi ini telah memenuhi syarat keefektivan karena telah berhasil mencapai nilai tes hasil belajar siswa yang mencapai rata-rata 79,04 diatas KKM yang ditetapkan yaitu 72, dan persentase tingkat ketuntasan minimal siswa mencapai 95,83\%.
\end{abstract}

Kata-kataKunci: hasil belajar siswa, kualitas media, media pembelajaran

Pada hakekatnya kegiatan belajar mengajar adalah suatu proses komunikasi. Proses komunikasi (proses penyampaian pesan) harus diciptakan atau diwujudkan melalui kegiatan penyampaian dan tukar menukar pesan atau informasi oleh setiap guru dan perserta didik. Peserta didik sebagai raw input dan subjek pendidikan memiliki ciri khas individu yang perlu dipahami oleh pendi- dik, diantaranya peserta didik adalah individu yang memiliki potensi fisik dan psikis yang khas, sehingga merupakan insan yang unik, peserta didik sebagai individu yang sedang berkembang, individu yang membutuhkan bimbingan individual dan perlakuan manusiawi, dan individu yang memiliki kemampuan untuk mandiri (Sanjaya, 2010). 
Menurut Ali (2004), proses belajar mengajar secara formal di sekolah terjadi interaksi antara berbagai komponen pengajaran. Komponenkomponen itu dapat dikelompokkan ke dalam tiga kategori utama, yaitu: (1) guru, (2) isi atau materi pelajaran dan (3) siswa. Interaksi antara ketiga komponen utama melibatkan sarana dan prasarana seperti metode, media, dan penataan lingkungan tempat belajar, sehingga tercipta situasi belajar-mengajar yang memungkinkan tercapainya tujuan yang telah direncanakan sebelumnya. Dengan demikian, guru yang memegang peranan sentral dalam proses belajar mengajar, setidak-tidaknya menjalankan tiga macam tugas utama, yaitu merencanakan, melaksanakan pengajaran dan memberikan balikan.

Guru harus mampu melayani dan mengakomodasi kebutuhan siswa yang heterogen. Namun dalam dalam pelaksanaannya, proses ini menemui beberapa kendala yang menyebabkan proses pendidikan tidak dapat berjalan dengan optimal, sehingga berdampak pada kualitas peserta didik yang rendah. Berdasarkan beberapa pengalaman para guru dalam membelajarkan sains khususnya Biologi di SMP, ditemukan permasalahan-permasalahan diantaranya, sebagian besar siswa kurang termotivasi dalam mengikuti pembelajaran, sehingga berujung pada rendahnya hasil belajar siswa. Rendahnya minat siswa untuk belajar Biologi berdampak pada rendahnya respon siswa terhadap pembelajaran Biologi. Siswa menganggap Biologi itu sulit dimengerti karena banyaknya hafalan dari buku teks dan tidak adanya visualisasi yang cukup untuk setiap bahasan materi ajar. Faktor yang diduga menjadi penyebab permasalahan ini adalah adanya faktor ekstrinsik seperti metode pembelajaran yang monoton, media mengajar yang kurang variatif, dan sajian materi pada buku ajar yang kurang menarik. Di samping itu, guru masih dianggap sebagai satu-satunya sumber belajar dan sumber informasi.

Mencermati hal-hal yang menjadi sumber permasalah tersebut, faktor guru, metode dan media menjadi faktor yang sangat berpengaruh dalam proses pembelajaran dan dalam menentukan keberhasilan belajar siswa, sebab proses pembelajaran merupakan komunikasi interaktif yang kompleks dan mencakup dua kegiatan yaitu proses belajar yang dilakukan oleh siswa dan proses mengajar yang dilakukan oleh guru. Posisi guru sebagai instrumental input dalam pendidikan harus mempunyai kompetensi yang baik da- lam hal mendidik dan membelajarkan untuk dapat melaksanakan tugas dengan baik dan benar.

Oleh karena itu, untuk mengatasi permasalahan yang dihadapi siswa dalam belajar seorang guru dituntut untuk selalu melakukan inovasi dan dapat menemukan kiat-kiat baru untuk menciptakan suasana belajar yang kondusif serta menyenangkan (enjoyable learning) yang dapat meningkatkan minat siswa terhadap pelajaran yang disampaikan. Hal ini perlu dilakukan karena aspek yang terpenting adalah minat siswa terhadap pelajaran sains itu sendiri. Minat siswa terhadap suatu pelajaran tersebut menimbulkan motivasi siswa untuk mempelajari dan menyenangi mata pelajaran tersebut. Dalam upaya menimbulkan minat tersebut, dapat dilakukan dengan menumbuhkan emosi positif siswa (seperti rasa senang dan rasa puas) dalam belajar. Dengan adanya minat, siswa akan termotivasi untuk belajar yang pada akhirnya akan dapat meningkatkan hasil belajar yang dicapainya.

Salah satu solusi untuk memecahkan masalah ini adalah dengan menggunakan media pembelajaran yang menarik. Media pembelajaran merupakan salah satu sumber belajar yang dapat menyalurkan pesan sehingga membantu guru dalam menyampaikan materi pembelajaran dengan lebih mudah dan efektif. Media berperan sangat penting sebagai pembawa informasi dari sumber (guru) menuju penerima (siswa). Untuk itu, penggunaan media yang tepat dan menarik akan menumbuhkan minat, rasa ingin tahu, motivasi dan kreativitas siswa, sehingga sangat penting untuk mengotimalkan ketercapaian tujuan pembelajaran. Hal ini sependapat dengan Munadi (2008) bahwa media yang bersifat interaktif dengan komputer memiliki beberapa kelebihan, diantaranya: (1) meningkatkan motivasi belajar, dimana dengan terakomodasinya kebutuhan siswa, maka siswa pun akan termotivasi untuk terus belajar, (2) memberikan umpan balik, dimana media pembelajaran interaktif dapat menyediakan umpan balik yang segera terhadap hasil belajar yang dilakukan oleh peserta didik, dan (3) kendali program sepenuhnya berada pada pengguna, yaitu siswa. Meninjau hal tersebut, maka perlu dicoba dikembangkan media pembelajaran yang interaktif berbasis teknologi komputer untuk dapat memfasilitasi cara belajar siswa dan proses pembelajaran di kelas. Dengan adanya media ini diharapkan akan dapat memperbaiki cara belajar siswa SMP yang sebagian besar mengandalkan hafalan daripada pemahaman, sebagaimana tujuan dari penelitian ini yaitu untuk 
meningkatkan hasil belajar siswa SMP terhadap mata pelajaran Biologi. Sehingga tujuan pembelajaran Biologi dapat mencapai seperti yang diharapkan semua pihak

\section{METODE}

Jenis penelitian yang digunakan adalah penelitian pengembangan (Research and Development) dengan produk berupa media pembelajaran interaktif Biologi. Media ini, dirancang berbasis komputer dengan menggunakan bantuan software Adobe flash CS3. Media berisikan materi Biologi yaitu sistem gerak pada manusia. Penelitian dilaksanakan di SMP Negeri 3 Kintamani Bangli, padakelas VIIIA semester Ganjil tahun pelajaran 2014/2015. Subjek penelitian ini adalah guru Biologi kelas VIII SMP Negeri 3 Kintamani dan siswa kelas VIIIA SMP Negeri 3 Kintamani tahun pelajaran 2014/2015 yang berjumlah 24 orang. Kelas VIIIA dipilih secara acak untuk mewakili kelas VIII yang ada, karena pihak sekolah telah mengelompokkan kelas VIII secara heterogen.

Teknik analisis data menggunakan analisis deskriptif yang berkaitan dengan aspek kepraktisan dan efektivitas melalui angket (kuesioner) dan tes hasil belajar biologi siswa. Data rata-rata respon guru $(R G)$ dan rata-rata respon siswa $(R S)$ yang diperoleh dikonversi menjadi nilai kualitatif berdasarkan kategori 3,5 $₫ \mathrm{RG} / \mathrm{RS} \leq 4,00$ (sangat positif); 2,50 $₫ \mathrm{RG} / \mathrm{RS}<3,50$ (positif); $1,50 \unlhd \mathrm{RG} /$
$\mathrm{RS}<2,50$ (kurang positif); 1,00 $\mathrm{RG} / \mathrm{RS}<1,50$ (sangat kurang positif) (diadaptasi dari Sadra, 2007). Untuk hasil tes siswa diharuskan memperoleh persentase ketuntasan $\geq 75 \%$ karena kriteria ketuntasan minimal (KKM) sekolah untuk mata pelajaran IPA adalah 72 berdasarkan Permendiknas Nomor 20 tahun 2007 tentang Standar Penilaian. Sedangkan untuk rata-rata motivasi siswa $(R M)$ yang diperoleh dikonversi menjadi nilai kualitatif berdasarkan kategori 4,50 $₫ \mathrm{RM} \unlhd, 00$ (sangat tinggi); 3,50 $\mathrm{RM}<4,50$ (tinggi); 2,50 $₫ \mathrm{RM}<3,50 \quad$ (sedang); $1,50 \unlhd \mathrm{RM}<$ 2,50 (rendah) dan, 1,00 $\mathrm{RM}<1,50$ (sangat rendah).

\section{HASIL DAN PEMBAHASAN}

\section{Hasil}

Hasil penelitian ini adalah produk media pembelajaran inteaktif Biologi yang praktis dan efektif. Penetapan materi dilakukan dengan mengkaji kurikulum IPA, silabus dan buku pegangan siswa sehingga diperoleh suatu tema yang cocok untuk dikemas dalam media pembelajaran interaktif berbasis komputer. Tema yang dipilih adalah Tubuh Manusia, dengan materi pokok Sistem Gerak pada Manusia (rangka dan otot). Materi ini ada pada materi pelajaran IPA SMP sesuai Kurikulum 2013. Berikut ini hasil pengembangan media pembelajaran Biologi.

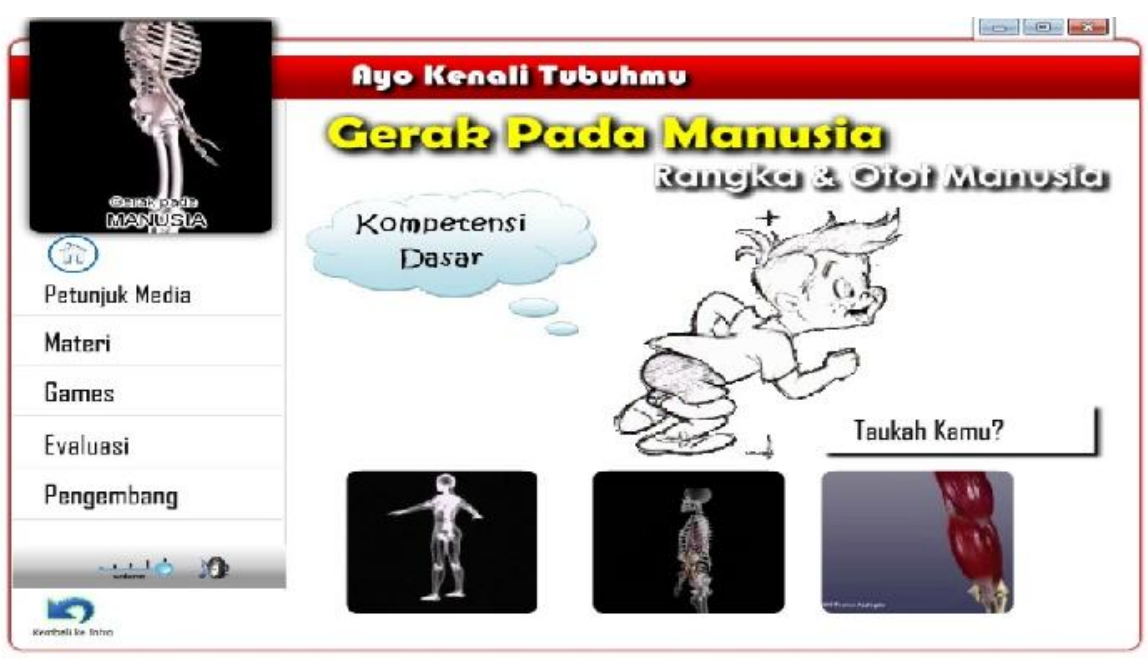

Gambar 1. Tampilan Halaman Menu Utama (home) 


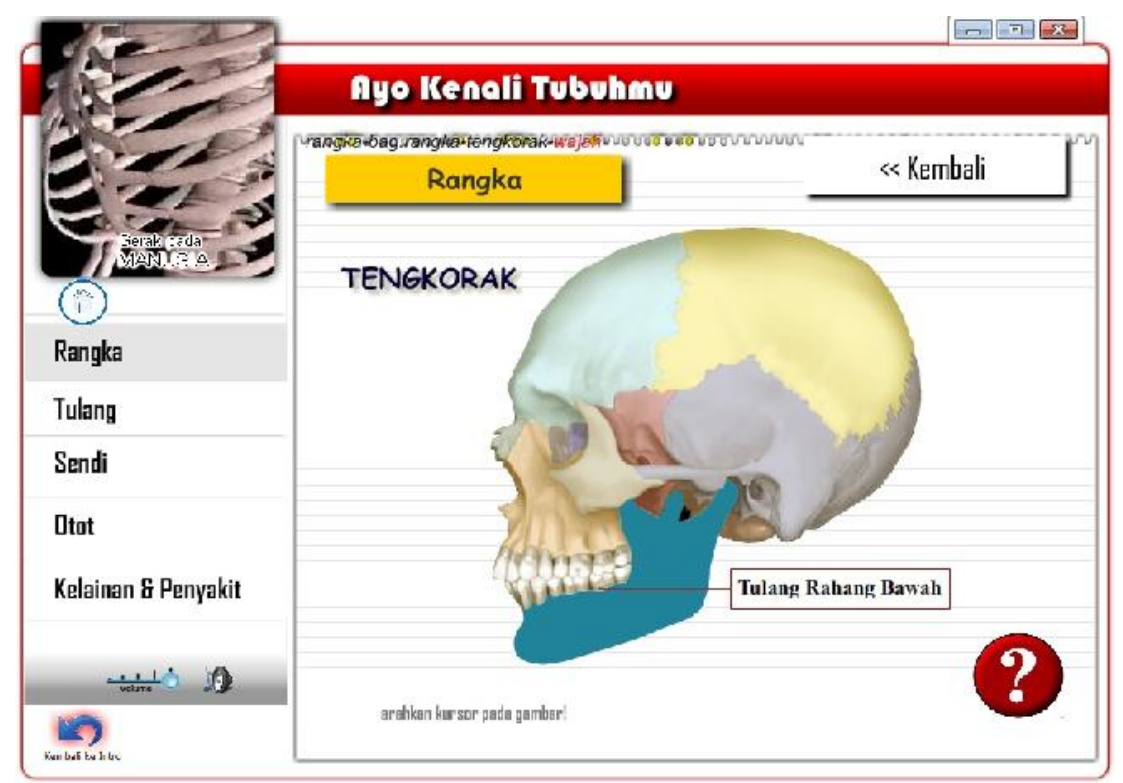

Gambar 2. Tampilan Halaman Penampil Materi

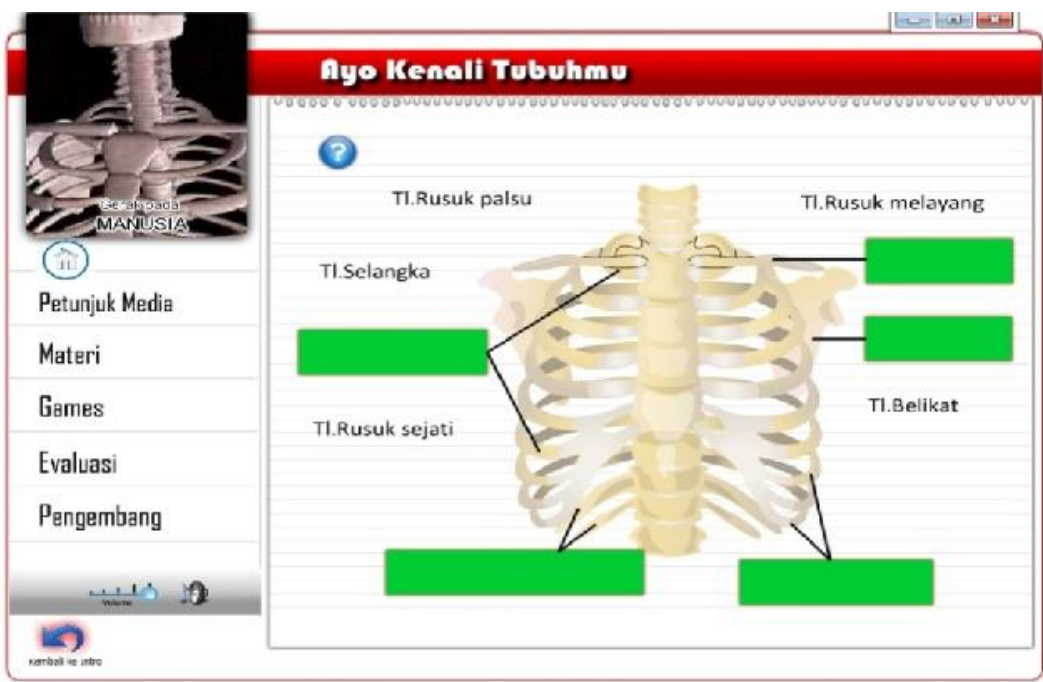

Gambar 3. Tampilan Halaman Games

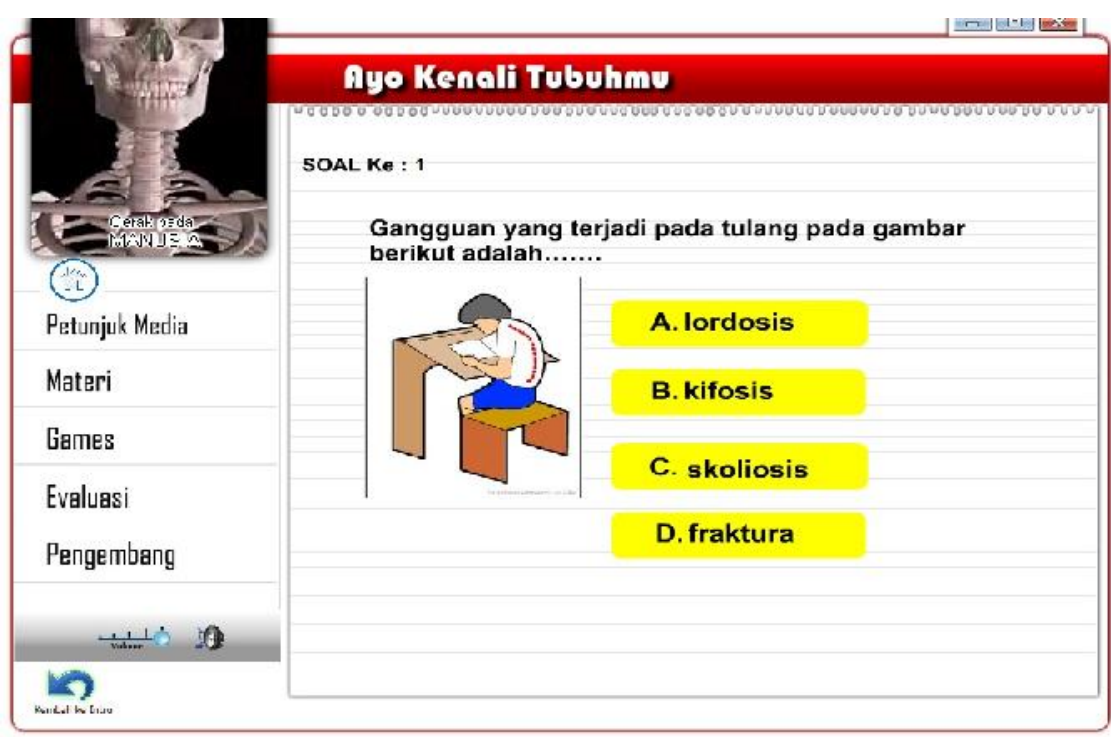

Gambar 4. Tampilan Halaman Evaluasi 
Kepraktisan media pembelajaran diukur dari respon guru terhadap media pembelajaran dan respon siswa terhadap media pembelajaran. Berikut ini disajikan tabel hasil analisis aspek kepraktisan.

Tabel 1. Hasil Analisis terhadap Angket Respon Guru

\begin{tabular}{crccc}
\hline \multirow{2}{*}{ No. } & \multirow{2}{*}{ Instrumen } & \multicolumn{2}{c}{ Hasil penilaian } \\
\cline { 3 - 4 } & & Skor rata-rata & Kategori \\
\hline 1 & Media Pembelajaran & 3.7 & SP \\
\hline 2 & LKS & 3.8 & SP \\
\hline 3 & RPP & 3.7 & SP \\
\hline 4 & Buku Petunjuk Penggunaan Media & 3.7 & SP \\
\hline & Rata-rata total & $\mathbf{3 . 7 3}$ & SP \\
\hline
\end{tabular}

Tabel 2. Hasil Analisis Terhadap Angket Respon Siswa

\begin{tabular}{crcc}
\hline \multirow{2}{*}{ No. } & \multirow{2}{*}{ Instrumen } & \multicolumn{2}{c}{ Hasil penilaian } \\
\cline { 3 - 4 } & & Skor rata-rata & Kategori \\
\hline 1 & Media Pembelajaran & 3.19 & SP \\
\hline 2 & LKS & 3.61 & SP \\
\hline 3 & Buku Petunjuk Penggunaan Media & 3.67 & SP \\
\hline & Rata-rata total & $\mathbf{3 . 5}$ & SP \\
\hline
\end{tabular}

Keefektivan media pembelajaran diukur dari motivasi belajar siswa menggunakan media pembelajaran yang dikembangkan dan tes hasil belajar siswa. Untuk mengetahui keefektivan media pembelajaran dilakukan dengan: 1) memberikan angket motivasi belajar siswa, dan 2) memberikan tes hasil belajar.Hasil analisis ini dapat dilihat pada Tabel 3 dan 4 berikut ini.
Tabel 3. Hasil Skor Angket Motivasi Belajar Siswa

\begin{tabular}{cccc}
\hline No. & $\begin{array}{c}\text { JumlahSiswa } \\
\text { (orang) }\end{array}$ & $\begin{array}{c}\text { Rata- } \\
\text { Rata } \\
\text { Skor }\end{array}$ & Keterangan \\
\hline 1 & 24 & 3.78 & Tinggi \\
\hline
\end{tabular}

Tabel 4. Hasil Skor Tes Hasil Belajar Siswa

\begin{tabular}{|c|c|c|}
\hline No. & Jumlah Siswa (orang) & Rata-Rata Nilai \\
\hline 1 & 24 & 79.04 \\
\hline
\end{tabular}

\section{PEMBAHASAN}

Hasil-hasil penelitian yang telah diperoleh selanjutnya akan dipaparkan pada pembahasan ini. Adapun hasil penelitian yang dibahas meliputi tingkat kepraktisan media pembelajaran dan efektivitas media pembelajaran.

Kepraktisan media pembelajaran dapat diukur dari respon guru terhadap media pembelajaran dan respon siswa terhadap media pembelajaran. Media pembelajaran dikatakan praktis jika pengamatan terhadap respon guru dan siswa minimal memperoleh skor 2,5 termasuk dalam kategori baik/praktis dan hasil yang diperoleh telah melebihi syarat minimal tersebut, yaitu 3.73 untuk respon guru dan 3.5 untuk respon siswa. Hasil penilaian kepraktisan media ini mendukung hasil penelitian yang dilaksanakan oleh Semadiartha (2012), dimana dalam penelitian tersebut diperoleh rata-rata skor respon guru sebesar 3,70

\begin{tabular}{lcc} 
Ketuntasan (\%) & $\begin{array}{c}\text { DayaSerap } \\
(\%)\end{array}$ & Keterangan \\
\hline 95.83 & 79 & Tuntas \\
dengan kategori sangat positif dan rata-rata skor \\
respon siswa sebesar 3,5 dengan kategori sangat \\
positif.
\end{tabular}

Kepraktisan media pembelajaran disebabkan karena guru dan siswa mudah memanfaatkan media pembelajaran sesuai dengan situasi dan kondisi siswa, guru dan sekolah, ketersediaan komponen pendukung (komputer), serta alokasi waktu yang ditentukan sehingga siswa dan guru memberikan respon positif terhadap pembelajaran yang telah dilakukan. Di samping itu, metode pembelajaran menggunakan media interaktif membuat penyampaian informasi lebih cepat dan mudah, serta dapat mempermudah siswa untuk memperoleh informasi yang efektif dan menarik siswa untuk mempelajari Biologi (Yulmaini dan Septina 2008).

Media pembelajaran yang dikembangkan juga mengintegrasikan komponen permainan sehingga membantu memudahkan siswa untuk me- 
mantapkan konsep materi, bersemangat, termotivasi dan belajar dalam suasanan yang menyenangkan. Mahtarami dan Irvansayah (2010), menyatakan penggunaan permaianan sebagai media pembelajaran lebih efektif untuk memperdalam materi. Pendapat ini senada dengan pernyataan Dani (2008), yang mengungkapkan bahwa education game merupakan salah satu alat bantu dalam pengajaran baik untuk siswa maupun guru yang cukup efektif dalam membantu guru (tutor) dalam menyampaikan materi pendidikannya sehingga daya serap siswa lebih tinggi dibandingkan dengan cara konvensional. Alasan yang mendasari pendapat tersebut diantaranya: (1) siswa cepat menyerap informasi dan pengetahuan dari materi yang disampaikan, (2) gambar, video, dan animasi dalam media lebih menarik dibandingkan teks, (4) interaktif, dan (5) berorientasi kepada pemecahan masalah.

Menurut tanggapan guru penggunaan media interaktif mempermudah guru dalam proses pembelajaran untuk mencapai tujuan yang diharapkan, karena di dalamnya terdapat cakupan materi yang lengkap. Materi dalam media pembelajaran sudah memenuhi SK dan KD yang harus dicapai, sesuai dengan perkembangan ilmu dan teknologi, mudah dipahami, serta penyajian dan bahasa yang digunakan sudah baik. Kelebihan media pembelajaran adalah meningkatkan minat belajar siswa karena bisa menunjukan materi secara kontekstual, pembelajaran tidak monoton karena melibatkan TIK dan menciptakan variasi metode pembelajaran. Hal ini selaras dengan pendapat Chen dan Chung (2011) bahwasanya multimedia menyajikan informasi dengan tampilan dan cara yang beragam, tidak hanya menyajikan kenyamanan secara visual dan auditori pada pebelajar, namun multimedia juga mampu meningkatkan minat dan efek belajar dan juga selaras dengan pendapat Li (2008) dimana memanfaatkan teknologi informasi untuk menyajikan materi melalui efek animasi, audio visual maka pebelajar akan terangsang dan termotivasi untuk semakin ingin menggali dan memahami pembelajaran. Pembelajaran menggunakan media pembelajaran meningkatkan kemandirian siswa juga kemampuan menggunakan teknologi dalam pembelajaran. Siswa berhadapan langsung dengan komputer sehingga memberikan pengalaman baru bagi siswa. Siswa juga merasa tertantang untuk menemukan jawaban pada LKS dan memperoleh skor tinggi pada games dan evaluasi dengan cara mengeksplorasi materi yang terdapat dalam media pembelajaran, sehingga siswa lebih fokus pada kegiatan pembelajaran dan siswa lebih mudah dikondisikan.

Media pembelajaran interaktif yang dikembangkan dapat memotivasi siswa dalam belajar. Hal ini terlihat dari hasil rata-rata skor angket motivasi belajar yang menunjukkan motivasi belajar siswa berada pada kategori tinggi yaitu 3,78 . Adanya motivasi belajar siswa ini membantu dalam mencapai hasil belajar yang optimal. Motivasi tersebut timbul karena media pembelajaran membuat siswa belajar mandiri dengan suasana yang menyenangkan. Pendapat ini senada dengan pernyataan Arsyad (2011) yang menyatakan bahwa media pembelajaran dapat meningkatkan dan mengarahkan perhatian anak, sehingga dapat menimbulkan motivasi belajar, interaksi yang lebih langsung antara siswa dan lingkungannya, dan memungkinkan siswa untuk belajar sendiri-sendiri sesuai dengan kemampuan dan minatnya. Suasana pembelajaran yang menarik, berbeda dari biasanya serta menyenangkan mempermudah siswa dalam belajar, sehingga akan berakibat pada pencapaian pemahaman siswa terhadap materi menjadi baik.

Tahap terakhir pengembangan media pembelajaran ini adalah menguji tingkat keefektifan produk pengembangan ini dalam proses pembelajaran. Hasil penelitian menunjukkan nilai tes hasil belajar siswa didapatkan rata-rata 79,04 dan dari 24 orang siswa mencapai ketuntasan 95,83\% jika dilihat dari nilai KKM dan nilai rata-rata motivasi diperoleh sebesar 3,78 dengan kategori tinggi. Oleh karena itu, media pembelajaran yang dikembangkan dapat dikatakan efektif. Hasil ini mendukung penelitian yang dilaksanakan oleh Khikmah (2013), dimana hasil uji coba produk pengembangan berupa media CD interaktif yang diterapkan dalam proses pembelajaran biologi secara klasikal yaitu $\geq 80 \%$ siswa mencapai KKM yang ditetapkan (80).

Temuan ini merupakan pembuktian bahwa penggunaan media pembelajaran interaktif dalam pembelajaran dapat meningkatkan hasil belajar dan motivasi siswa. Hal ini terjadi karena media ini menjadikan proses pembelajaran menjadi lebih baik. Perbaikan proses belajar ketika pembelajaran menggunakan media pembelajaran interaktif dimungkinkan karena beberapa faktor, diantaranya: a) media interaktif ini mengubah pembelajaran yang statis menjadi dinamis, sehingga dapat membangkitkan minat belajar dan meningkatkan motivasi belajar, b) media dapat mengkonkretkan materi yang abstrak sehingga belajar siswa menjadi terstruktur, c) media bersifat inter- 
aktif sehingga mampu menjaga minat belajar siswa. Belajar dengan menggunakan media interaktif memecahkan dan melengkapi kekurangan pembelajaran tradisional di kelas, memperpanjang dan memperluas ruang pembelajaran dan memperkuat interaksi, d) media interaktif menyajikan pembeajaran yang menyenangkan, sehingga menumbuhkan minat belajar siswa. Media interaktif pada umumnya memiliki standar skenario, gambar hidup (dinamis), dan game menarik yang membawa siswa ke dalam lingkungan belajar yang santai dan menyenangkan, e) melatih keterampilan.

Ketika siswa mampu belajar cepat, maka ia akan mempercepat pembelajaran yang berlangsung menuju pada pembelajaran selanjutnya. Namun ketika seorang siswa mengalami kesulitan dalam proses belajarnya, maka ia dapat memberikan lebih banyak waktu untuk pembelajaran. Dengan kata lain, pengendalian komputer ini yang berada ditangan siswa dimana media interaktif mampu mengakomodasi siswa yang lamban menerima pelajaran, sehingga apabila pengendalian komputer berada ditangan siswa tingkat kecepatan belajar dapat disesuaikan dengan tingkat penguasaan. Berdasarkan hal ini, komputer dan media pembelajaran ini memungkinkan siswa melakukan individualisi pembelajaran yaitu mengendalikan laju dan urutan pembelajarannya, yang memberikan mereka lebih banyak kontrol terhadap hasil yang mereka capai. Arsyad (2011) mengemukakan komputer dapat mengakomodasi siswa yang lamban menerima pelajaran, karena komputer dapat memberikan iklim yang lebih efektif dengan cara yang lebih individual. Hal ini senada dengan pernyataan Smaldino (2011) bahwa, media pembelajaran berbasis komputer memberikan beberapa keuntungan antara lain: a) individualisasi pembelajaran, b) mampu mengakomodasi kebutuhan khusus siswa, c) mampu memberikan pantauan terhadap hasil belajar siswa, d) memungkinkan terjadinya manajemen informasi, 5) memberikan pengalaman belajar multisensorik, 6) meningkatkan partisipasi pebelajar. Dari enam keuntungan menggunakan media pembelajaran berbasis komputer yang dinyatakan oleh Smaldino tersebut, produk pengembangan ini ditekankan pada dua keuntungan yakni indi-

\section{DAFTAR RUJUKAN}

Adri, M. 2007. Strategi Pengembangan Multimedia Instruksional Design. Jurnal Invotek. I (VII): 1-9. vidualisasi pembelajaran dan memberikan pengalaman belajar multisensorik.

Keefektivan media pembelajaran interaktif terhadap hasil belajar juga dikarenakan media tersebut dapat memvisualisasikan materi yang bersifat abstrak dan sulit untuk dilihat secara langsung. Adri (2007) bahwa multimedia mempunyai fungsi khusus berupa teknologi animasi, simulasi dan visualisasi, siswa mendapatkan informasi yang lebih real dari informasi yang bersifat abstrak sehingga akan dapat mengembangkan aspek kognitifnya. Media pembelajaran interaktif ini juga menampilkan informasi materi disertai kegiatan evaluasi yang diaplikasikan dalam bentuk games, sehingga menjadikan suasana belajar yang menyenangkan dan tidak membosankan. Penelitian Rohwati (2012) menyimpulkan bahwa penggunaan education game baik secara teori maupun empirik dalam pembelajaran dapat meningkatkan hasil belajar dan aktivitas siswa, karena siswa belajar dengan senang dan santai, namun tetap serius. Pembelajaran juga lebih hidup dan siswa lebih menikmati, karena siswa belajar sambil memanfaatkan teknologi komputer yang semula belum maksimal penggunaannya.

\section{SIMPULAN}

Berdasarkan hasil penelitian dan pembahasan yang telah dipaparkan, dapat disimpulkan bahwa media pembelajaran interaktif Biologi yang dikembangkan telah mampu meningkatkan kualitas pembelajaran di SMP Negeri 3 Kintamani, hal ini tercermin dari tingginya motivasi belajar siswa dengan perolehan skor rata-rata sebesar 3,78 dan meningkatnya hasil belajar siswa yang terlihat dari nilai tes hasil belajar siswa yang mencapai rata-rata 79,04 diatas KKM yang ditetapkan sekolah sebesar 72, sertaketuntasan belajar siswa mencapai $95,83 \%$ yang artinya telah memenuhi persentase tingkat ketuntasan minimal yang ditetapkan sebesar $275 \%$.

Berdasarkan simpulan yang ditemukan di atas, disarankan agar pengembangan media pembelajaran seperti ini hendaknya juga dikembangkan untuk pokok bahasan atau kompetensi dasar lain pada mata pelajaran IPA khususnya atau mata pelajaran lain pada umumnya.

Ali, M. 2004. Guru Dalam Proses Belajar Mengajar. Bandung: Sinar baru Albensindo. 
Anwas, O. M. 2002. Pengembangan Model Pembelajaran Kelas Rangkap Berbantuan Media Audio di Sekolah Dasar. Jurnal Pendidikan dan Kebudayaan.(Online), 038(8), (http://www.go. id/Jurnal/38/pengembangan\% 20model.htm, diakses18 Agustus 204)

Arikunto,2012.Prosedur Penilaian Suatu Pendekatan Praktek. Jakarta: Rineka Cipta.

Arsyad, A. 2011. Media pembelajaran. Jakarta: PT Raja grafindo Persada.

Chen, C.Y. \& Chung, W.L. 2011. Research on The Learning Effects of Multimedia Assisted Instruction on Mandarin Vocabulary for Vietnamese Students: a Preliminary Study Involving e-learning System. Educational Research Reviews. (Online) 6(17): 919-927. (http//www.academic-jour-nals. org, diakses15Juli 2012)

Dani, M. 2008. Pembelajaran Interaktif dan Aktraktif Berbasis Game dan Animasi untuk Pendidikan Dasar Dan Menengah di Indonesia. Makalah ini disampaikan pada Konferensi dan Temu Nasional Teknologi Informasi danKomunikasi untuk Indonesia. Jakarta: e-Indonesia Initiative

Daryanto. 2010. Media Pembelajaran, Peranannya Sangat Penting Dalam Mencapai Tujuan Pembelajaran. Yogyakarta. Gava Media.

Depdiknas. 2003. Media Pengajaran. Jakarta: Depdiknas.

Depdiknas. 2006. Model Pembelajaran Terpadu IPA. Jakarta: Pusat Kurikulum

Hadi, S. 2001. Metodologi Research untuk Penulisan Paper, Skripsi, Thesis dan Disertasi, Jilid Tiga. Yogyakarta: Penerbit Andi.

Istianda, M \& Darmanto. 2009. Pembuatan Multimedia sebagai Upaya Peningkatan Layanan Bantuan Belajar. Jurnal Pendidikan Terbuka danJarak Jauh. I (X): 11-17.

Khikmah, T.Y. 2013. Pengembangan Media Pembelajaran CD Interaktif Materi Struktur dan Fungsi Sel Dilengkapi Teka-Teki Silang Berbasis Flash. Skripsi. Universitas Negeri Malang.
Li, J.L. 2008. The Effects of the Presentation Method of Multimedia Teaching Approach on the Learning Efficacy of Lower Grade Elementary School Students. National Hsinchu University of Education (in Chinese).

Mahtarami A \& Irvansyah MN. 2010. Pengembangan Game Pembelajaran Otomata Finit. Makalah ini disampaikan pada Seminar Nasional Informatika, UPN "Veteran". Yogyakarta 22 Mei 2010

Munadi, Y. 2008. Media Pembelajaran; Sebuah Pendekatan Baru. Jakarta: Gaung Persada Press.

Rohwati M. 2012. Penggunaan Education Game untuk Meningkatkan Hasil Belajar IPA Biologi Konsep Klasifikasi Makhluk Hidup. Jurnal PendidikanIPA Indonesia, 1 (1):7581.

Sadra, I Wayan. 2007. Pengembangan Model Pembelajaran Matematika Berwawasan Lingkungan dalam Pelatihan Guru Kelas I Sekolah Dasar. Disertasi tidak diterbitkan. Surabaya: Universitas Negeri Surabaya.

Sanjaya, W. 2010. Kurikulum dan Pembelajaran. Jakarta: Kencana Prenada Media Group.

Semadiartha. 2012. Pengembangan Media Pembelajaran Berbasis Komputer dengan Microsoft Excel yang Berorientasi teori Van Hiele pada Bahasan Trigonimetri kelas X SMA untuk Meningkatkan Prestasi dan Motivasi Belajar Matematika Siswa. Tesis tidak diterbitkan.Singaraja: Program Pascasarjana Universitas Pendidikan Ganesha Singaraja.

Slavin, R.E. 2011. Psikologi Pendidikan: Teori dan Praktik. Diterjemahkan oleh Marianto Samosir. Jakarta: Pt. Indeks

Smaldino, S.E., Lowther, D.L. \& Rusell, J.D. 2011. Teknologi dan Media untuk Belajar. Diterjemahkan oleh Arif Rahman. Jakarta: Kencana.

Yulmaini \& Septina, N. 2008. Perangkat Pembelajaran Biologi untuk Sekolah Menengah Umum (SMU). Makalah ini disampaikan padaSeminar Nasional Informatika, UPN "Veteran", Yogyakarta. 